\title{
Negotiating Value
}

\author{
Diogo Santos \\ UNIVERSIDADE DE LISBOA
}

\section{RESUMO}

Sundell (2016) apresenta razões que minam a tese de que termos avaliativos são semanticamente distintos dos demais termos gradativos - i.e., que os termos avaliativos são genuinamente avaliativos e/ou que a relativização a um padrão determinado pelo avaliador/experienciador se encontra codificada na semântica desses termos. De modo a minar essa tese, Sundell argumenta que a persistência de desacordos estéticos pode ser explicada sem que se suponha que termos avaliativos sejam genuinamente avaliativos, considerando tais desacordos negociações metalinguísticas - desacordos acerca de como uma certa expressão ou palavra deve ser usada. Mostrando que uma explicação que apela a negociações metalinguísticas faz o trabalho necessário sem que se assuma que avaliativos são literalmente avaliativos, o argumento expandido de Sundell (2016) pode ser resumido do seguinte modo: aceitando um princípio de parcimónia, termos avaliativos deveriam ser vistos como gradativos descritivos. Neste artigo, argumento que as negociações metalinguísticas não contam a história toda, mostrando que, se termos avaliativos não são literalmente avaliativos, as negociações metalinguísticas não dão conta da importante conexão entre o uso de termos avaliativos e as interações sociais entre agentes acerca de valor.

Palavras-chave: negociação metalinguística; desacordo persistente; avaliativos; termos finos.

\begin{abstract}
Sundell (2016) presents the grounds to undermine the claim that so called evaluative terms are semantically different from other gradable terms - i.e., that they are genuinely evaluative and/or that it is encoded in their semantics the relativization to a standard determined by an experiencer/appraiser. In order to undermine the claim, Sundell argues that the persistence of evaluative disagreements can be explained without assuming that aesthetic terms are indeed evaluative when one takes into
\end{abstract}


account metalinguistic negotiations - disagreements about how one should use a word or expression. By showing that metalinguistic negotiations do all the needed work without requiring that one assumes that aesthetic adjectives are literally evaluative, Sundell's expanded argument can be stated in the following way: for the sake of parsimony, one should treat evaluative terms as descriptive gradables. In the paper, I argue that metalinguistic negotiations cannot be the whole story by showing that, if one denies that evaluative terms are literally evaluative, metalinguistic negotiations do not account for the important connection between valuewords and social interactions about value.

Keywords: metalinguistic negotiation; persistent disagreement; evaluatives; thin terms.

\section{1-Introduction}

SUNDELL (2016) presents the grounds to undermine the claim that so called evaluative terms are semantically different from other gradable terms - i.e. that they are literally evaluative and that the relativization to a standard determined by an experiencer/appraiser is encoded in their semantics. In order to undermine it, Sundell argues that the persistence of evaluative disagreements can be explained without assuming that putative evaluative terms are indeed evaluative when one takes into account metalinguistic negotiations - disagreements about how one should use a word or expression. By showing that metalinguistic negotiations do all the needed work without requiring the assumption that they are literally evaluative, Sundell's argument is that for the sake of parsimony one should treat evaluative terms as descriptive gradables.

In the paper, I argue that metalinguistic negotiations cannot be the whole story by showing that an important connection between value-words and social interactions about value goes missing if one denies that evaluative terms are literally evaluative. I begin by explaining the two assumptions that Sundell is denying about evaluatives and how metalinguistic negotiations do the needed work in accounting for evaluative disagreements. I then show that something is missing from the picture; specifically, how the connection between some value-words and interactions on evaluative matters is stronger than the metalinguistic negotiations framework implies. 


\section{2 - Denying two assumptions}

The debate about the appropriate semantics for evaluatives is pervaded by two assumptions.

(A1) Evaluative adjectives are literally evaluative.

(A2) The relativization to a standard determined by the experiencer/appraiser is encoded in the semantics of the evaluative adjective.

(Sundell 2017:794)

(A1) means that evaluative adjectives, when used, literally express that the object to which the predicate purportedly applies to is good/ bad or that it is (dis)pleasing; while (A2) means that the object is pleasing/good to an experiencer/appraiser or that it is pleasing/good according to a standard that is not contextually provided, but already encoded in the semantics of the adjective (i.e. a standard determined by an experiencer/appraiser). The standard or experiencer/appraiser to which it is relativized to is usually thought to be an element of the evaluation that is encoded in the meaning of the adjective.

Many believe that evaluative disagreements are persistent - i.e., that they subsist even after the parties agree about all the descriptive facts relevant to the dispute. Their persistence is a strong indication that the disagreements are not about descriptive matters but about normative differences. So, if the latter depiction of what is going on with evaluative disagreements is on the right track, it is very natural to consider that (A1) and (A2) is the case.

Sundell (2016) advances the radical idea that both these assumptions are false and that so called evaluatives are not semantically different from other relative gradable adjectives. ${ }^{1}$ To argue for this, one

1 Sundell (2016) advances the suggestion that the two assumptions about aesthetic adjectives are false. While the suggestion is specifically applied to aesthetic adjectives, there does not seem to be a reason not to consider applying it to evaluatives across the board and this is what I will be assuming here. Although the claim that I will be assuming is stronger than Sundell's, assuming that (A1-2) are false across the board actually properly motivates their denial. Sundell's main motivation to reject both assumptions 
needs to argue that evaluative disagreements persist due to purely contextual features and that their persistence has nothing to do with the literal meaning of evaluative terms.

Thus, Sundell is required to provide an explanation of persistent disagreement that relies on a framework where the disagreement is not about the correctness of what is being literally expressed. The explanation is that speakers typically use purported evaluative terms metalinguistically - they use them to sharpen thresholds, scales, or the specific weight of dimensions (the latter only applies to multidimensional gradables, of course). This usage systematically occurs for gradables because their scales and thresholds are typical underspecified.

Consider a conversational context where Pau Gasol's height is shared knowledge among the participants and additionally it is shared knowledge that it is shared knowledge. In this context one can make sense of the claim that Pau Gasol is tall by interpreting the claim as not being about Pau Gasol's height per se, but about it hitting the threshold for tall (for a basketball player).

But how does one go from a sharpening usage to conveying evaluative information? The answer is that speakers, when using gradables metalinguistically, are proposing to their audience what (usually, according to them) should be the threshold or the scale of the term. In the case of metalinguistic usage, conveying the normative or evaluative content does not arise from the word being semantically evaluative. This paves the way for explaining the persistence of evaluative disagreements without assuming that value-words are literally evaluative. According to Sundell, the phenomenon of persistent disagreement can be completely and coherently accounted for with a metalinguistic negotiation framework.

\footnotetext{
is parsimony: 'If nearly every word in the language can be used as a value word, then for entirely independent reasons, we'll need an account of what makes particular usages evaluative. If we need an account like that anyways, then it may be a mistake to drive a categorical, semantic wedge between the "evaluative" and the "non-evaluative" terms.' (Sundell 2016: 799) The parsimony motivation is effective only if the 'semantic wedge between the "evaluative" and "non-evaluative" terms' is not present in other areas of evaluative discourse.
} 
Plunkett and Sundell (2013) introduce the notion of metalinguistic negotiation by characterizing it as a dispute that reflects a disagreement about how a certain expression should be used. For it to occur, it is necessary that, in the context of the dispute, speakers employ different metalinguistic usages of the expression.

\section{Consider the Secretariat example:}

\begin{abstract}
Consider the dispute I heard on WFAN (a sports talk radio station in New York) when Sports Illustrated announced its ' 50 greatest athletes of the 2oth Century.' Some listeners called in complaining that a horse - Secretariat - had made the list, while host Chris Russo defended the choice. Clearly this is a dispute about what should be in the extension of 'athlete', and the callers wanted to argue that a horse had no place here.
\end{abstract}

(Ludlow 2014:78)

The matter under dispute is about the meaning of the term 'athlete', and not about Secretariat's properties or even how each of the participants feels about the horse's accomplishments. The participants probably agree on all those issues. The dispute is normative, because it is about which concept should the use of the term express. ${ }^{2}$ The term 'athlete' is being used to refer to the word itself - or to its linguistic features - and not to denote a property. Since the disagreement is about what should count as part of the extension of the term 'athlete', resolving the dispute does not depend on any facts about Secretariat or other athletes. Whence the genuineness and persistence of the disagreement are properly accounted for.

2 Plunkett and Sundell describe the dispute in a very similar way: 'On this understanding of the dispute, each speaker literally expresses a true proposition given the concept they in fact express with their term. But beyond that, the speakers pragmatically advocate for the concept that they are using and in virtue of which they assert those propositions. Thus, their metalinguistic dispute reflects a genuine disagreement about how to use the word "athlete". In particular, it is a debate in conceptual ethics about which among a range of competing concepts, and in particular, which of $\mathrm{C}_{1}$ or $\mathrm{C}_{2}$, is most appropriate to the conversation and should be expressed by the term "athlete". (2013:17). 
Speakers engage in metalinguistic negotiations for different sorts of reasons. In this particular case, it is quite possible that the caller and the radio host are negotiating the usage of the word 'athlete' because they have competing views on personhood and those views are connected with what should count as an athlete, but that need not be what the purpose of the negotiation is. ${ }^{3}$ Its straightforward purpose is to determine a threshold for what counts as athlete, ${ }^{4}-$ i.e., whether a horse should count as an athlete - but its deeper purpose is to determine how human commitments toward non-human animals should be governed. Metalinguistic negotiations have social and historical import because meanings 'fill specific and important functional roles in our practices.' (Plunkett and Sundell 2013:20)

How speakers use words matters - socially and historically. Some word-meanings are more crucial to human social interactions than others, that is why some words, typically called evaluatives, are more prone to be used metalinguistically than others - or so can Sundell claim. The view, thus, accounts for what looks like every bit of important data. It accounts for:

i) the persistence of evaluative disagreements,

ii) the evaluative nature of those disagreement,

iii) the genuineness of the disputes,

iv) the social and historical importance of value discourse, and

v) the systemically evaluative usage of a particular set of words, despite there not being a class of words which are semantically evaluative.

One might argue against the metalinguistic framework by claiming that evaluative terms are literally evaluative precisely because they have played an important functional role in our practices. At some point, this role must have been

3 See Rast (2020) on this. It is unclear what could be the motivation for the dispute given the absence of more information; notwithstanding, the motivation for the dispute need not conflate with what the disagreement is or with what its purpose is about. An indication that the two should not be conflated is that the metalinguistic dispute holds even if the parties share the same view on personhood.

4 If the case is supposed to be a metalinguistic negotiation, it better be that the candidate properties for an entity to count as an athlete are gradable - rationality, linguistic competence, physical ability... 
determined and that feature is plausibly part of the core meaning of evaluative adjectives. ${ }^{5}$ I believe Sundell would be on board with this. The only commitment he is required to take is that the aforementioned functional role is triggered via the descriptive meaning of so-called evaluative terms.

\section{3 -What is missing}

Consider another example: the UN and the Bush Administration disagree about whether waterboarding should count as torture. ${ }^{6}$ For the Bush/Cheney Administration, American interests at the time dictated that waterboarding should not be considered torture, for it was - according to the administration - an effective method to get crucial information to avoid potential terrorist attacks. Since American interests and UN goals did not converge on this matter, the two parties disagreed on how they should use the word 'torture'.

Nonetheless, the dispute has moral import because what should be included in the extension of the concept torture is a fundamental moral issue. The parties engaging in the metalinguistic negotiation are engaging in the negotiation of a normative issue about how the word 'torture' should be used, but they are also engaging in a negotiation about morality, for what counts as torture is importantly connected with what agents find inadmissible in western liberal societies. What one finds (in)admissible largely determines how one

5 A related worry is spelled out by Rast (2016:408): '[I]s this [the functional role of an expression not depending substantially on the concept it expresses] really plausible? To me it is not, for it seems hard to find a way in which a social practice with regards to a term may come into being without being based on a widely accepted meaning of that term, or in other words, because the term has that specific meaning and not another one.' Although the worry is understandable, proponents of the metalinguistic framework endorse that the social practice with regards to a term comes into being because the term has a specific descriptive meaning that is of import to our practices; it so happens that the meaning is prone to negotiation (perhaps this is not by chance, though), due to the under specification of their scale, threshold, or dimension. What they need not endorse is that those same practices come into being because the term is evaluative. 6 For the purpose of the example, I am assuming the Bush Administration was being sincere - i.e., the institution believed waterboarding does not count as torture. 
acts; hence, metalinguistic negotiation seems to get the appropriate connection between metalinguistic usages and conative attitudes.

So, the dispute between the UN and the Bush/Cheney Administration is not just about word-use, it is also moral. But if Sundell is on the right track and there is nothing evaluative in the semantics of the word 'torture' how can the dispute turn out to be moral too, i.e. about what is impermissible? The dispute is moral to the extent that our use of the word 'torture' has moral import. Said moral import, if one wants to take the denial of (A1) seriously, cannot be a result of the term's putative evaluative meaning, it must be explained by appealing to its metalinguistic usage.

Thus, the explanation would have to go something like this: 'torture' word-use matters morally because its descriptive meaning is appropriately connected with the present social fabric and moral interactions. It is because moral interactions have developed in a particular way that whatever act is considered torture is considered impermissible and this results in an appropriate link between the descriptive meaning of the term (which in some regard can be negotiated) and the present social structures.

This link is accidental and fairly loose. The link between 'torture' word-use and morality can break apart if different social structures are in place. This means that negotiating 'torture' word-use in other historical contexts where torture is largely practiced and socially accepted does not lead to moral considerations. The dispute about 'torture' metalinguistic usage in those historical contexts would still be normative - for it would be about how one should use 'torture'-but negotiating, e.g., which actions one should apply the word to, would not lead to a negotiation about which actions are impermissible.

This may seem plausible about the word 'torture', which is a thick(er) term, but what about paradigmatic examples of thin terms? ${ }^{7}$ For instance, the negotiation of the usage of the moral thin term 'wrong' seems to attach to the different social structures much more firmly. 7 For details on the thin/thick distinction see e.g.: Eklund 2001, Värynen 2013 and
Williams 1985. 
Imagine the following disagreement between Dick Cheney and Kofi Annan - now deploying the metalinguistic use of the word 'wrong', instead of 'torture':
Annan: Mr. Vice President, you need to understand that waterboarding is wrong.
Cheney: No, I don't, because waterboarding isn't wrong.

The depiction of the disagreement between Annan and Cheney under the metalinguistic negotiation framework is that they are negotiating the usage of 'wrong', whether or not it should apply to waterboarding. What is particular about this negotiation is not that it also leads to moral considerations about waterboarding and, hence, that it has moral import. Its particularity is that, whatever the social makeup is, the normative negotiation about the use of 'wrong' leads to a disagreement that has moral import. Arguably, this is so because moral thin terms attach to social structures differently, more tightly than moral thick(er) terms do. This can be explained if we assume that (A1) obtains: it is their purely evaluative meaning that explains that 'wrong' attaches to social practices more firmly than, for instance, 'torture' does.

My claim is that, even conceding that most evaluative disagreements are about word-usage, that cannot be the whole story; specifically, when it comes to negotiating the usage of thin terms. The link between the metalinguistic negotiation of these terms and its evaluative considerations - including the conative attitudes associated with those considerations - is not as loose as Sundell's proposal implies. The objection may be summarized as follows: disputes that involve thin terms - i.e. terms whose content is typically considered fully non-descriptive - invariably trigger disagreements for the right reasons; for reasons that are moral, aesthetic, and so on. This is a distinctive feature when one compares it with the behavior of at least some thick terms - those whose content is typically considered to be partially descriptive. That distinctive behavior is an additional explanatory burden which exclusively metalinguistic negotiation frameworks are unable to bear. 


\section{4-Conclusion}

The case I am making for a semantic class of evaluative terms is fairly straightforward - and follows the steps of other criticism against the metalinguistic negotiation framework. ${ }^{8} \mathrm{I}$ have argued that metalinguistic negotiations cannot be the whole story, because evaluatives latch in a distinctive way onto the diverse human social structures. Descriptives, even when used evaluatively, do not display the same behavior. The use of 'beautiful', 'tasty', 'funny'... invariably triggers aesthetic considerations; the use of thin moral adjectives like 'wrong', 'ought'... invariably triggers moral considerations. This evaluative invariability can only be explained if one assumes (A1).

\section{REFERENCES}

Eklund, Matti. (2011). 'What are thick concepts?'. Canadian Journal of Philosophy, 41(1), pp. 25-49. doi:10.1353/cjp.2011.0007.

Ludlow, Peter. (2014). Living Words: Meaning Underdetermination and the Dynamic Lexicon. Oxford: Oxford University Press.

Marques, Teresa. (2017). 'What metalinguistic negotiations can't do'. Phenomenology and Mind, 12, pp. 40-8.

Plunkett, David and Timothy, Sundell. (2013). 'Disagreement and the semantics of normative and evaluative terms'. Philosophers' Imprint, 13(23).

Rast, Erich. (2020). 'The theory theory of metalinguistic disputes'. Mind and Language. 10.1111/mila.12355.

Rast, Erich. (2017). 'Value disagreement and two aspects of meaning'. Croatian Journal of Philosophy, 17(51), pp. 399-430.

Sundell, Timothy (2016). 'The tasty, the bold, and the beautiful'. Inquiry: An Interdisciplinary Journal of Philosophy, 59(6), pp. 793-818.

Väyrynen, Pekka (2013). The Lewd, the Rude and the Nasty: A Study of Thick Concepts in Ethics. Oxford University Press.

Williams, Bernard (1985). Ethics and the Limits of Philosophy. Cambridge, MA: Harvard University Press.

$8 \quad$ See e.g. Marques 2017. 